\title{
A Study of Variation in Physiognomic Characteristics of Guinea Savanna Vegetation
}

\author{
Abdullahi Jibrin ${ }^{1}$ \\ ${ }^{1}$ Department of Geography, Ahmadu Bello University, Zaria, Nigeria \\ Correspondence: Abdullahi Jibrin, Department of Geography, Ahmadu Bello University, Zaria, Nigeria. Tel: \\ 234-803-697-8420. E-mail: abdullahi717@hotmail.com
}

Received: December 28, 2012 Accepted: February 16, 2013 Online Published: February 20, 2013

doi:10.5539/enrr.v3n2p52

URL: http://dx.doi.org/10.5539/enrr.v3n2p52

\begin{abstract}
Variation in structural composition of Guinea savannah vegetation was investigated in Kpashimi forest reserve, Niger State, Nigeria. Field work inventory was conducted to determine the current status of the vegetation physiognomic characteristics of the six physiographic units in the study area; comprising of Riparian Forest, Savannah Woodland, Degraded forest Scrubland, Grassland, and Bare surface. Parameters measured include tree density, trunk diameter, basal area, tree density, tree species diversity, tree height, crown cover, shrub cover, and grass cover. The aim of the study is to determine and compare the variation in structural characteristics of the vegetation of the study area. Analysis of variance (ANOVA) showed significant differences amongst virtually all the parameters among the physiographic units. In general, the landscape of the forest reserve has been influenced significantly by anthropogenic disturbance and the resulting landscape vegetation cover is a mixture of natural and human managed mosaics that vary in shape, size, structure and arrangement. Thus, drastic measures need to be taken so as to reverse the trend and to mitigate the far reaching ecological consequences of vegetation degradation as highlighted in this study. Access to UNFCC carbon credit is hereby recommended for the management of the study area.
\end{abstract}

Keywords: structure, composition, diversity, guinea savanna, field inventory, physiognomic characteristics, Landscape ecology

\section{Introduction}

The composition and structure of any given vegetation community reflects the interaction between its component members and their environment through time (Turner et al., 2001). Consequently, any natural or man induced changes will definitely result in corresponding minor or major changes in the affected vegetation community (Millennium Ecosystem Assessment [MA], 2005). Vegetation structure may be considered as the organization of individuals that form a stand, vegetation type or plant association (Edwards, 1983). Von Gadow (1999) extended the concept to include the distribution of any tree characteristic within a forest or stand. It is therefore not only possible to describe stand structure in terms of growth form, stratification and coverage, species, tree size (through diameter, height, crown dimensions or other quantity), sex, stress symptoms or mortality, but also in terms of the spatial distribution of these characteristics within an area and in relation to each other.

The word "structure" generally considers the composition of a population of trees in terms of specific characteristics. These may include tree age, size, species or sex. Spatial structure, on the other hand looks at the arrangement of such characteristics in space. Spatial diversity refers to the arrangement of the characteristics in relation to each-other or in relation to a particular point on the ground (Lyon \& Sagers, 1998; Green et al., 2006). According to Graz (1996). The structure and state of the vegetation in general is a function of the present and past actions and interactions of an array of factors which may be divided into two groups. These are the determining factors that govern the potential vegetation composition in terms of species and on the other hand, the modifying factors that alter the environment so that it may favour one species or growth form over another, or affect individual species or growth forms directly. He further posited that while the determining factors are primarily rainfall and those factors influencing the soil moisture balance, the modifying factors are primarily of anthropogenic origin, mainly in the form of resource extraction, including land clearing and grazing of domestic animals, and fire.

From the foregoing review, the woodland savannah vegetation of Kpashimi forest reserve is vulnerable to being 
affected by an array of factors. This would result in significant structural and spatial diversity, both within stands, and over a wider area. However, several authors have attested to dearth of reliable forest inventory data on vegetation physiognomic structure and composition in the developing countries (FAO, 2010; FDF, 1998; Daniel \& Ayobami, 2007). On the local scale, knowledge on structural characteristics of vegetation as well as standardised inventories of these properties are required in order to expand understanding of ecosystem processes, to relate vegetation maps to ecological properties and as basis for modelling approaches. Therefore, the aim of the study is to determine and compare the variation in structural characteristics of the vegetation of the Kpashimi forest reserve in the guinea savannah belt of Niger state in Nigeria. The working hypothesis is that:

Ho: There is no significant differences in the current structural composition of the vegetation cover in Kpashimi forest reserve.

\section{Theory of Landscape Ecology}

The conceptual framework of this study is based on the theory of landscape ecology which incorporates the study of biological, physical and societal factors of spatial and temporal variation in the landscape (Wu, 2008; Turner et al., 2001; Turner, 1989). Landscape ecology examines the appearance and patterns of land as a result of the interactions with its ecosystems. (Turner, 1989). Landscape ecology analyses configuration (the arrangement of elements), connectivity (continuity of a habitat across a landscape), Fragmentation, (the breakup of a landscape in to patches or spots), and patch (an area that differs in some way from the surrounding landscape) (Turner et al., 2001; Wu \& Hobbs, 2007). Heterogeneity is the measure of how different parts of a landscape are from one another. A landscape with structure and pattern implies that it has spatial heterogeneity, or the uneven distribution of objects across the landscape (Forman, 1997). Structure is determined by the composition, the configuration, and the proportion of different patches across the landscape, while Pattern is the term for the contents and internal order of a heterogeneous area of land. (Forman \& Godron, 1986).

\section{Materials and Methods}

\subsection{Study Area}

The Kpashimi forest reserve is located in Gulu district of Lapai Local government Area in Niger State. The forest reserve lies between latitude $8^{\circ} 38^{\prime}$ to $8^{\circ} 52^{\prime}$ North and $6^{\circ} 34^{\prime}$ to $6^{\circ} 48^{\prime}$ East. It is situated about 50 kilometres south of Lapai town on the left hand side of the tarred road from Lapai to Gulu. The forest reserve covers approximately 231.21 square kilometres. It is characterised by alternating wet and dry season coded as 'Aw' by Koppen's classification (that is tropical rainy climate with dry season in winter). The mean annual rainfall is about $1,300 \mathrm{~mm}$ with an average monthly temperature of about $28^{\circ} \mathrm{C}$ and an annual range of about $3^{\circ} \mathrm{C}$ (KFRMP, 2009).

The natural vegetation of the study area is Southern Guinea savannah characterised by the woodland vegetation type. If left undisturbed, the trees may form fairly close canopies and grass undergrowth that does not impede the observer from seeing through is formed (Jaiyeoba \& Essoka, 2006). Prominent among such trees are Ceiba pentandra, Tamarindus indica, Adansonia digitata and Mangifera indica. Others are Vitex doniana, Vitaleria paradoxa, Borassus aethiopum, Afzelia africana, Acacia albida, Khaya senegalenesis, Parkia bigloboza, Daniellia oliveri, Ficus sycomorus, Pterocarpus erinaceus. They are covered with mostly annual grass such as Rhynchelytrum repens, Panicum kerstingii, Setaria pallide-fusca, Aristida sp. and Hackelochloa granularia. Generally, the land use characteristics of the study area include forestry, farming, grazing, quarrying, hunting and gathering. These activities form important part of the economy of the subject area (KFRMP, 2009). 


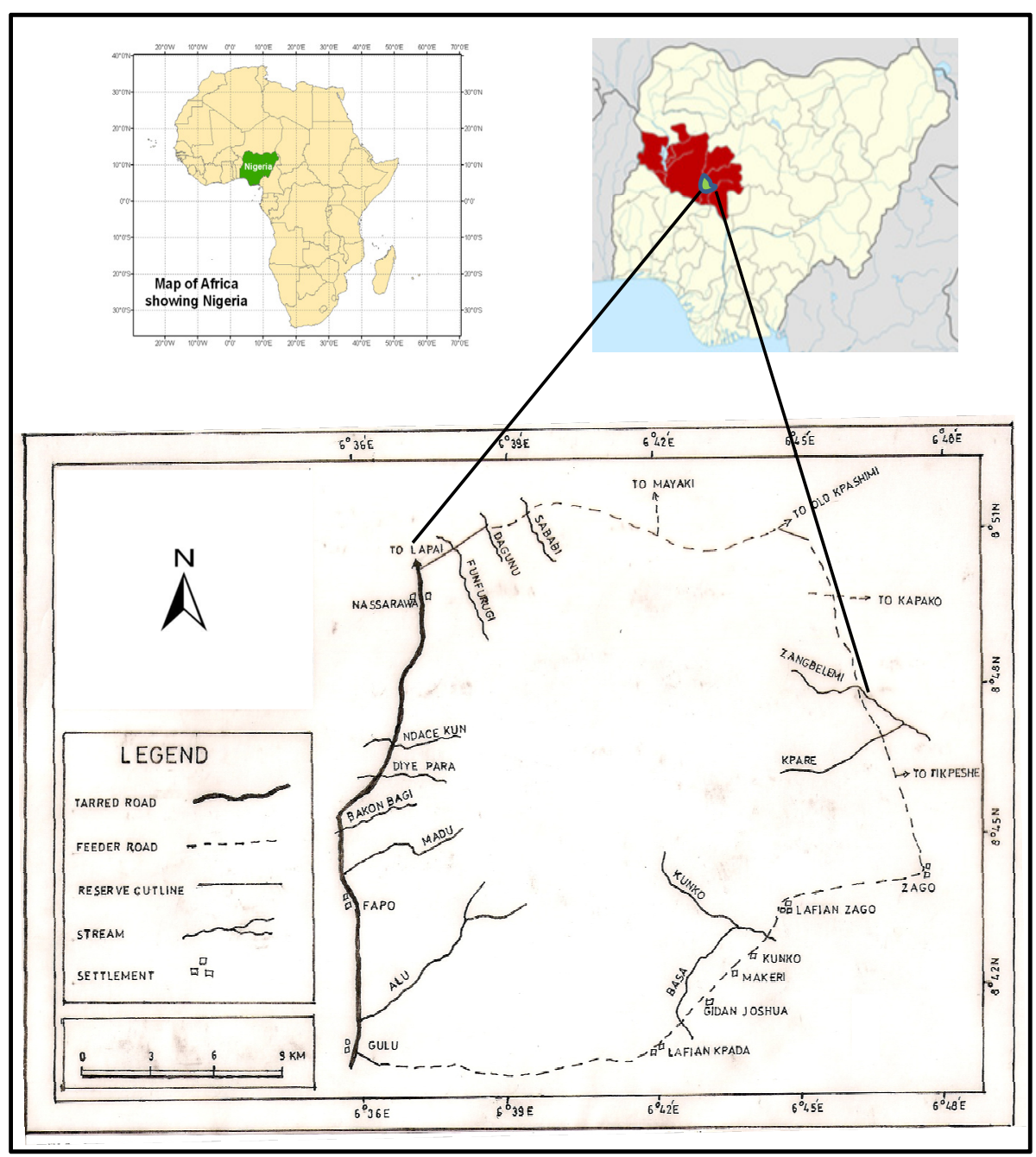

Figure 1. Map of study area showing the location of Kpashimi Forest Reserve

Source: Niger State Forest Management Unit.

\subsection{Methods}

\subsubsection{Determination of Sample Plot Number, Size and Location}

Stratified random sampling was adopted in order to capture the variability of land cover (Rosenfield, 1982). The strata were based on the initial classification of satellite imagery, from where different classes of land cover were obtained. Selection of samples was done by visual display and analysis of the NIGERIASAT-1 classified image of 2007, using Arc GIS 9.2. On display, the vegetation cover classes were identified. Eight pixels selected from each of the vegetation classes; by recording their coordinates which made up a total of 48 sampling units. Justice and Townshend (1981) Model was applied for the determination of sample size. The model estimates the size of any sample quadrat as function of the pixel size and the expected geometric accuracy of the images.

$$
\mathrm{A}=[\mathrm{PD}(1+2 \mathrm{PG})]^{2}
$$

Where:

$A=$ Area to be sampled

$\mathrm{PD}=$ Ground diameter of a pixel

$\mathrm{PG}=$ Geometric accuracy of the image

Thus, NIGERIASAT-1 with pixels that are 32 meter in diameter on the ground and are located to an accuracy of \pm 0.5 pixels, the sample plot size used for the study is 0.4096 hectares or 64 meter by 64 meter. 


\subsubsection{Measurement of Vegetation Parameters}

Species height measurement: The vertical length between the lowest part of the tree and the tallest living part for all trees more than three meters in height measured in meter. A clinometers was used to determine the angle of elevation, while the distance from the foot of the tree to the observer was recorded. The height of the observer at eye level was noted and the height of the tree was subsequently determined by using the formula (Gareth, 1991)

$$
\mathrm{X}=\mathrm{Y} \mathrm{x} \tan \AA+\mathrm{Z}
$$

Where:

$\mathrm{X}=$ tree height

$\mathrm{y}=$ distance from the tree to the observer

$\AA=$ angle of elevation

$\mathrm{z}=$ height of the observer at eye level

Tree Girth: (Trunk Diameter at Breast Height): Circumferal measurement of all trees more than 3 meters in height, at 1.5 meters breast height, measured in meters. Measurement is done with the aid of a measuring tape (Eyre et al., 2006).

Tree Species Density and Diversity: The degree of concentration and frequency of tree species in a particular area. This was obtained by enumerating and recording total number of trees more than three meters in height and respective species found within the sample plot. (Eyre et al., 2006)

Density $=$ Total number of species in quadrat $/$ Size of quadrat

In order to investigate the extent of plant diversity within the forest reserve, diversity indices were calculated for physiographic units using the inverse of Simpson's (1949) diversity index. Species diversity is a measure of heterogeneity of a site taking into consideration the number and the density of individual species. It is expressed as:

$$
I=\frac{N\{N-1\}}{\sum\{n i(n i-1)\}}
$$

Where:

$I=$ Simpson's diversity index

$N=$ Total number of species enumerated

$n i=$ Number of individuals of ith species enumerated

The inverse of the original Simpson index was used so as to remove the ambiguity in the original Simpson index, hence the higher the value of $I$, the greater the heterogeneity.

Crown Cover: Estimation of canopy cover of a tree or group of trees in each quadrat, measured in percentage. Based on line intersect method, trees whose projected canopy intersect the 64 meter transect, observed between 11:00 am and 1:00 pm; when the sun is at its zenith were recorded. The total length of the projected canopy is then divided by the total length of the tape to give an estimate of crown cover (Eyre et al., 2006).

Crown cover $=$ Total estimated crown cover $\mathrm{x} 100$ / Total length of transect

Basal Area: Cross sectional area of the trunk for trees more than 3 meters in height at 1.5 meters above the ground, measured in square metre. This parameter was determined based on the formula by Wratten and Fry, (1980)

$$
\text { Basal area }=C^{2} / 4 \pi
$$

Where:

$C=$ girth size (diameter at breast height).

$\pi=22 / 7=3.14$

Shrub cover and Grass cover: Estimation of shrub cover and grass cover in each quadrat measured in percentage. Separate measurements were carried out for Shrub cover and grass cover respectively using transect method (Eyre et al., 2006). 


\subsubsection{Data Analysis}

For the data analysis, descriptive statistics such as mean, standard deviation, and coefficient of variation were calculated for each of the vegetation parameters. The differences in the vegetation physiognomic characteristics were tested by F- ratio variant of ANOVA. Computation analysis was carried out with the aid of statistical software - SPSS 15.0 (Windows Evaluation Version- 2006)

\section{Results and Discussion}

The summary of data obtained from biometry field measurement is presented in Table 1 below.

Table1. Variation in structural composition of vegetation

\begin{tabular}{|c|c|c|c|c|c|c|c|c|}
\hline \multirow{2}{*}{\multicolumn{2}{|c|}{$\begin{array}{c}\text { PHYSIOGNOMIC } \\
\text { CHARACTERISTICS }\end{array}$}} & \multicolumn{6}{|c|}{ VEGETATION COMMUNITIES } & \multirow{2}{*}{$\begin{array}{l}\text { ANOVA } \\
\text { (F-Ratio) }\end{array}$} \\
\hline & & \multirow{2}{*}{$\begin{array}{c}\text { BARE } \\
\text { SURFACE } \\
0.0025\end{array}$} & \multirow{2}{*}{$\begin{array}{c}\text { GRASS- } \\
\text { LAND } \\
0.0041\end{array}$} & \multirow{2}{*}{$\begin{array}{c}\text { SCRUB- } \\
\text { LAND } \\
0.0063\end{array}$} & \multirow{2}{*}{$\begin{array}{c}\text { DEGRADED } \\
\text { FOREST } \\
0.0074\end{array}$} & \multirow{2}{*}{$\begin{array}{c}\text { SAVANNA } \\
\text { WOOD } \\
\text { LAND } \\
0.0129\end{array}$} & \multirow{2}{*}{$\begin{array}{c}\text { RIPARIAN } \\
\text { FOREST } \\
0.0103\end{array}$} & \\
\hline \multirow{3}{*}{$\begin{array}{l}\text { Tree Density } \\
\qquad\left(\mathrm{M}^{2}\right)\end{array}$} & $\overline{\mathbf{X}}$ & & & & & & & \multirow{3}{*}{$31.342^{*}$} \\
\hline & SD & 0.0009 & 0.0010 & 0.0019 & 0.0023 & 0.0029 & 0.0018 & \\
\hline & CV \% & 36 & 24.4 & 30.2 & 31.1 & 22.5 & 17.5 & \\
\hline \multirow{3}{*}{$\begin{array}{l}\text { Species } \\
\text { Diversity }\end{array}$} & $\overline{\mathbf{X}}$ & 3.68 & 5.38 & 7.13 & 9.38 & 13.75 & 7.88 & \multirow{3}{*}{$36.696^{*}$} \\
\hline & SD & 0.74 & 1.19 & 2.10 & 1.60 & 2.19 & 1.55 & \\
\hline & CV \% & 20.4 & 22.1 & 29.5 & 17.1 & 15.9 & 19.6 & \\
\hline \multirow{3}{*}{$\begin{array}{l}\text { Tree Girth } \\
\text { (Meter) }\end{array}$} & $\overline{\mathbf{X}}$ & 0.54 & 0.43 & 0.71 & 0.81 & 1.03 & 1.16 & \multirow{3}{*}{$15.415^{*}$} \\
\hline & SD & 0.19 & 0.18 & 0.27 & 0.19 & 0.15 & 0.20 & \\
\hline & CV \% & 35.2 & 41.9 & 38.0 & 23.5 & 14.6 & 17.2 & \\
\hline \multirow{3}{*}{$\begin{array}{l}\text { Basal Area } \\
\quad\left(\mathrm{M}^{2}\right)\end{array}$} & $\overline{\mathbf{X}}$ & 0.026 & 0.019 & 0.046 & 0.056 & 0.085 & 0.110 & \multirow{3}{*}{$12.145^{*}$} \\
\hline & SD & 0.017 & 0.014 & 0.040 & 0.026 & 0.024 & 0.039 & \\
\hline & CV \% & 65.4 & 73.7 & 87.0 & 46.4 & 28.2 & 35.5 & \\
\hline \multirow{3}{*}{$\begin{array}{l}\text { Tree Height } \\
\text { (Meter) }\end{array}$} & $\overline{\mathbf{X}}$ & 11.3 & 17.6 & 17.2 & 17.5 & 19.0 & 26.6 & \multirow{3}{*}{$26.112^{*}$} \\
\hline & SD & 3.10 & 3.10 & 2.45 & 2.12 & 1.45 & 3.56 & \\
\hline & CV \% & 27.4 & 17.6 & 14.2 & 12.1 & 7.6 & 13.4 & \\
\hline \multirow{3}{*}{$\begin{array}{l}\text { Crown cover } \\
\text { (Percentage) }\end{array}$} & $\overline{\mathbf{X}}$ & 4.75 & 10.30 & 19.14 & 36.65 & 57.40 & 67.73 & \multirow{3}{*}{$81.754^{*}$} \\
\hline & SD & 5.95 & 4.97 & 8.85 & 8.99 & 9.32 & 9.13 & \\
\hline & CV \% & 125.7 & 48.2 & 46.2 & 24.5 & 16.2 & 13.5 & \\
\hline \multirow{3}{*}{$\begin{array}{l}\text { Shrub cover } \\
\text { (Percentage) }\end{array}$} & $\overline{\mathbf{X}}$ & 20.03 & 28.29 & 64.81 & 35.34 & 35.95 & 11.09 & \multirow{3}{*}{$18.586^{*}$} \\
\hline & SD & 7.24 & 10.86 & 16.54 & 16.20 & 12.78 & 2.48 & \\
\hline & CV \% & 36.1 & 38.5 & 25.5 & 45.8 & 35.5 & 22.4 & \\
\hline \multirow{3}{*}{$\begin{array}{l}\text { Grass cover } \\
\text { (Percentage) }\end{array}$} & $\overline{\mathbf{X}}$ & 51.11 & 89.86 & 27.84 & 32.64 & 25.81 & 18.83 & \multirow{3}{*}{$75.933^{*}$} \\
\hline & SD & 7.09 & 6.27 & 15.10 & 6.64 & 7.34 & 4.61 & \\
\hline & CV \% & 13.9 & 7.0 & 54.2 & 20.3 & 28.4 & 24.5 & \\
\hline
\end{tabular}

Source: Field work, 2008.

NOTE: * Significant at $0.01(\alpha=3.51)$

$\overline{\mathbf{X}}=$ mean

SD $=$ Standard deviation

$\mathbf{C V}=$ Coefficient of variation

$\mathbf{N}=48$

$\alpha=$ Hypothetical value of $F$ from distribution table

With reference to Table 1 Analysis of variance (ANOVA) showed significant differences amongst virtually all 
the parameters among the physiographic units at $\mathrm{P}<0.01$ level. The forest reserve is characterised by vegetation communities with significantly varying tree number and density per unit area. It is evident that there is significant variation in species diversity among the vegetation cover of Kpashimi forest reserve. Based on frequency of occurrence, Vitallaria paradoxa, Irvingia gabonensis, Parkia biglobosa, Prospis Africana, Daniela oliveri, Detarium Marcrocarpa and Anagasius leocarpus are the species most commonly found in the Savanna woodland, Degraded forest, Scrubland, and Grassland areas. In contrast, most common species found in Riparian forest include Khaya senegalensis, Anogeissius leocarpus, Daniela oliveri, Antiaris Africana and Cola gigantia. Savanna woodland records highest density of tree stand and diversity. Therefore, with Savanna woodland having the highest mean value of the inverse of Simpson's (1949) diversity index (13.75) and lowest coefficient of variation, it suggests that Savanna woodland is most diverse in terms of species variety. It thus follows that tree species diversity varied according to the disturbance gradient in the different vegetation communities as it was observed that tree density and species diversity consistently decrease with more evidences of human activities. Scientific studies such as Allen and Barnes (1985), and Yeaton (1988), illustrate the apparent effect of farming, logging and bush burning activities in the modification of the original vegetation. This result confirms Myers (1989) assertion that in many states of Nigeria, relatively little natural vegetation remain untouched by human activities.

Data on tree basal area of the various vegetation communities as indicated in Table 1 exhibit similar pattern with that of the tree girth and varied according to the disturbance gradient. The result of ANOVA computed to test for differences between tree heights of the various vegetation communities show that the variation is statistically significant at $(\mathrm{P}<0.01)$ level. The observed variation could be explained by the effect of the nature and intensity of land use practices identified in the various vegetation communities.

With regards to crown cover, as indicated in Table 1, Riparian forest recorded the highest mean value of $67.7 \%$, followed by Savanna woodland (57.4\%), Degraded forest (36.65\%), Scrubland (19.1\%) and Bare surface (4.8\%). With reference to FAO (2001) minimum threshold standard for forest area; having trees of not less than 5 meters in height and crown cover not less than $10 \%$, within an area of not less than 0.5 hectares, Riparian forest and Savanna woodland of the study area with over $40 \%$ of crown cover, fulfil conditions of closed forest, while Degraded forest and scrubland with crown cover ranging between $10 \%$ and $40 \%$, corresponds with open forests. However, Grassland and Bare surfaces are short of reaching the threshold and are rather categorised as Other Wooded Land (OWL).

Shrub cover varies significantly among the vegetation physiographic units. Areas covered by Scrubland, grassland Bare surface, and Degraded forest that show more evidence of human activities tend to have high proportion of shrub cover due to high rate of deforestation in such areas. The study also revealed that there is significant variation in the proportion of grass cover from one location to another in the study area. The predominance of grass cover in Grassland, Bare surface, Degraded forest and Scrubland might be the result of high intensity of deforestation in such areas and natural adaptability of grass species to Savanna ecological zone.

Figure 2 presents a graphical picture of variations in the structural composition of the vegetation in the study area. Findings revealed that the Riparian forest has comparatively higher mean values of trunk diameter, basal area, tree height and crown cover. This class of vegetation cover constitute characteristics that resemble that of tropical high forest. The Savanna woodland records the highest density, comparatively moderate trunk diameter, basal area, tree height, and crown cover. Both Riparian forest and Savanna woodland show little or no evidence of human activities and hence are somewhat well preserved. 

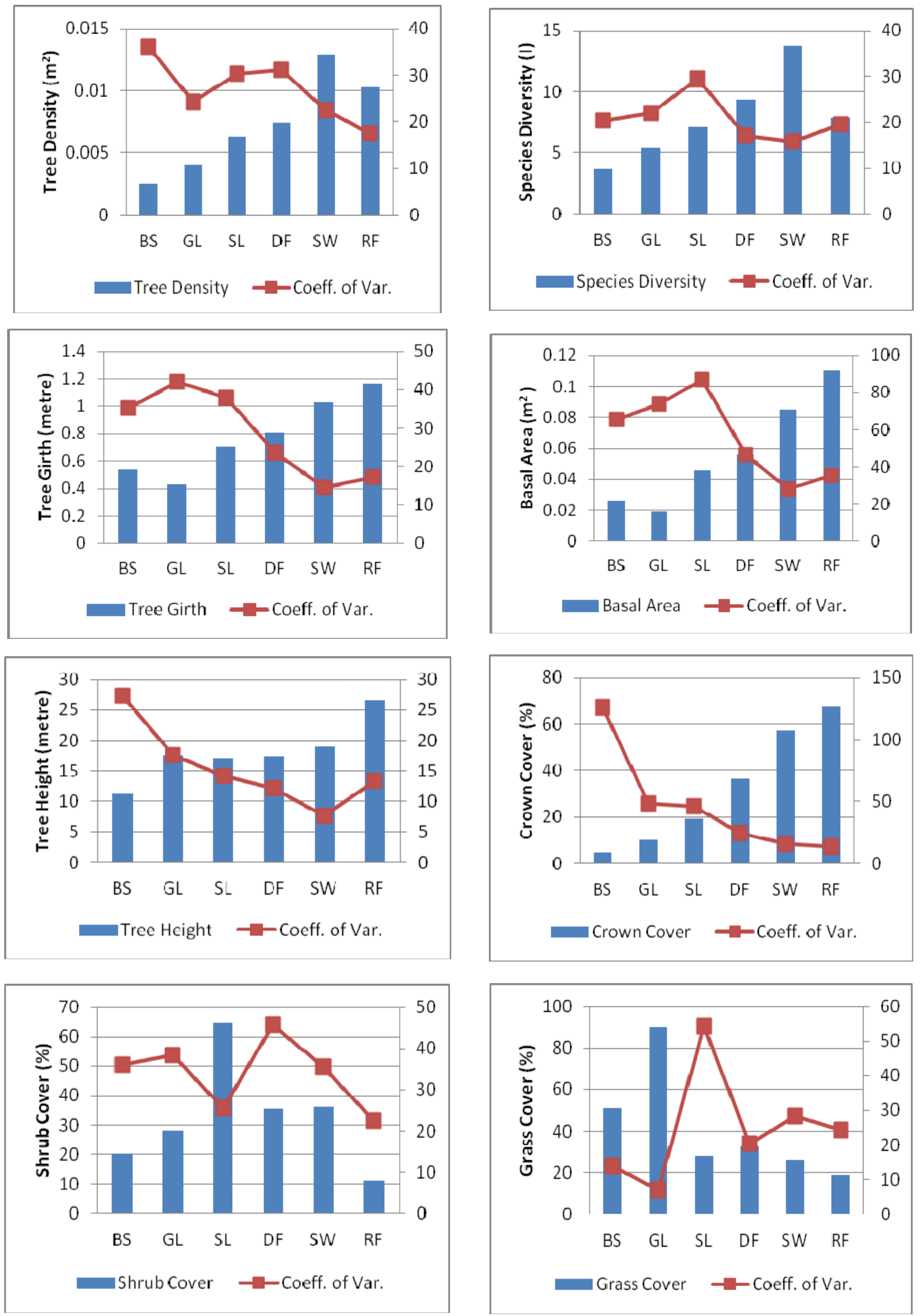

Figure 2. Variations in the physiognomic characteristics

Note: $\mathrm{BS}=$ Bare Surface; GL $=$ Grassland; SL $=$ Scrubland; DF= Degraded Forest; SW $=$ Savanna Woodland; $\mathrm{RF}=$ Riparian Forest; Coeff. of Var.= Coefficient of Variation; I=Simpson Diversity Index. 
In contrast, the Degraded Forest, Scrubland, Grassland and Bare surface are characterised by high mean values of grass cover, Shrub cover, but with comparatively low trunk diameter, crown cover, tree height and tree density These vegetation communities seem to have resulted from degradation of the forest reserve as these areas are composed of younger trees undergoing regeneration. By implication, the older and more matured vegetation in these areas have been greatly affected by wood exploitation, grazing and bush burning. However, the rate and intensity of these activities vary from one location to another. More so, the impact of climate variability on the structural characteristics of vegetation cover cannot be underestimated.

Some observed threats to the structural characteristics of the vegetation cover of the forest reserve include farming, grazing, illegal logging, bush meat hunting, bush burning, collection of Non Timber Forest Products, and encroachment by human settlement. The observed underlying causes of these threats include poverty, business opportunity, ignorance and corruption. The variations in the structural composition of the vegetation communities were also statistically significant at $(\mathrm{P}<0.01)$ level (Table 1). Consequently, the null hypotheses for the study is hereby rejected.

\section{Summary and Conclusion}

The impression one gets from the preceding analysis is that there are significant variations in the spatial distribution of vegetation physiognomic characteristics over the study area. The variations could be attributed to both natural and human factors. ANOVA computed for each of the physiognomic characteristics show that the observed variations or differences are significant at 0.01 level of significance. The forest landscape seems to be degraded and fragmented and currently characterised by mixed forest patches with significantly varying structural characteristics. Thus, the resulting landscape mosaic varies in shape, size, arrangement and structure.

This study provides the basis for monitoring vegetation landscape dynamics; which is an important factor to consider in the design of an environmental decision framework. It is necessary to protect these areas through restoration, rehabilitation or effective conservation programmes particularly by embarking on carbon project under the Clean Development Mechanism (CDM) of the Unite Nations Framework Convention on Climate Change (UNFCCC). It is equally important to point out that further studies over a longer period are necessary for better understanding of the relationship between changes in landscape structure, human impact and climate change.

\section{Acknowledgements}

I am grateful to the following: Professor Jaiyeoba, I. A., of the Department of Geography, Ahmadu Bello University, Zaria. Mallam M. A. Mohammad, Director, Forestry, Niger State Ministry of Environment and Forestry Resources, Minna; Mallam Shuaibu Koko, the then Area Forest Officer, Kpashimi Forest Reserve, Lapai for providing professional support and guidance for this study. We are also thankful to all people who assisted in the data collection in the study area as well as village forest guard who escorted and showed us the easy way in to the forest.

\section{References}

Allen, J. C., \& Barnes D. F. (1985). The causes of deforestation in Developing countries. Annals of Association of American Geographers, 75, 163-184. http://dx.doi.org/10.1111/j.1467-8306.1985.tb00079.x

Daniel, A. M., \& Ayobami, T. S. (2007). Application of remote sensing and GIS in land use/Land cover mapping and change detection in parts of South Western Nigeria. African Journal of Environmental Science and Technology, 1(5), 99-107.

Edwards, D. (1983) A broad-scale structural classification of vegetation for practical purposes. Bothalia, 14, 705-71.

Eyre. T. J., Kelly, A . L., \& Neldner, V. J. (2006). Methodology for the establishment and survey of Reference site for Bio conditions. Version 1.4. Environmental Protection Agency, Biodiversity Science Unit, Brisbone.

FAO. (2010). Global forest resources assessment 2010 country report: Nigeria Retreived from http://www.fao.org/forestry/ fra/67090/en/) on 12/10/2011

FDF. (1998). Assessment of vegetation and land use changes in Nigeria between 1976/78 and 1993/95. Prepared by Geomatics International, Canada, FDF, Abuja, Nigeria.

Forman, R. T. T. (1997). Landscape Mosaics: The ecology of landscapes and regions (pp. 213-256). Cambridge: Cambridge University Press.

Forman, R. T. T., \& Godron, M. (1986). Landscape Ecology. New York: John Wiley and Sons. 
Gareth Williams. (1991). Techniques and Fieldwork in Ecology (pp. 36- 47). Collins Educational, Great Britain.

Graz, F. P. (1996). Management of a Pterocarpus angolensis population under the influence of fire and land use. M. Sc. thesis, University of Stellenbosch, Stellenbosch, South Africa.

Green, D. G., Klomp, N. I., Rimmington, G. R., \& Sadedin, S. (2006). Complexity in Landscape Ecology, Springer, Amsterdam.

Jaiyeoba, I. A., \& Essoka, P. E. (2006). 'Soils and Vegetation' in The Middle Niger River Basin: A field course hand book. Department of Geography, Ahmadu Bello University, Zaria.

Justice, C., \& Townshend, J. (1981). Integrating Ground data with remote sensing. Terrain analysis and Remote sensing. In J. Townshend (Ed.), George Alien and Unwin, London.

KFRMP. (1999). Kpashmi Forest Reserve Management Plan. Forest Management Component, Kpashimi Forest Reverve.

Lyon, J., \& Sagers, C. L. (1998). Structure of herbaceous plant assemblages in a forested riparian landscape. Plant Ecology, 138, 1-16. http://dx.doi.org/10.1023/A:1009705912710

MA. (2005). Millemium Ecosystem Assessment: Ecosystem and Human well-being: Synthesis Report, Washington D.C. USA: Island Press.

Myers, N. (1989). Deforestation Rates in Tropical Forests and their Climatic implication. Friends of the Earth, London.

Rosenfield, G. H., Fitzpatrick, Lins, K., \& King, H. S. (1982). Sampling for Thematic map accuracy testing. Photogrammetry Engineering and Remote Sensing, 18, 131-137.

Simpson, E. H. (1949). Measurement of Diversity Nature, London.

Turner, M. G. (1989). Landscape ecology: The effect of Patterns on processes. Annual Review of Ecological System, 20, 171-191.

Turner, M. G., Gardner, R. H., \& O'Neill, R. V. (2001). Landscape Ecology in Theory and Practice. New York, NY, USA: Springer-Verlag. http://dx.doi.org/10.1146/annurev.es.20.110189.001131

Von Gadow, K. (1999). Waldstruktur und diversit at. Alg. Forst u. J.-Ztg., 170,117-122.

Wratten, S. D., \& Fry, G. L. A. (1980). Field Laboratory Techniques in Ecology, Edward Arnold, London.

Wu, J. (2008). Landscape ecology. In S. E. Jorgensen (Ed.), Encyclopedia of Ecology. Oxford: Elsevier. http://dx.doi.org/10.1016/B978-008045405-4.00864-8

Wu, J., \& Hobbs, R. (2007). Key Topics in Landscape Ecology. Cambridge: Cambridge University Press. http://dx.doi.org/10.1017/CBO9780511618581

Yeaton, R. I. (1988). Porcupines, fires and the dynamics of the tree layer of the Burkea africana savanna. Journal of Ecology, 76, 1017-1029. http://dx.doi.org/10.2307/2260630 